Author: P Bolton

MUNICIPAL TENDER AWARDS AND INTERNAL APPEALS BY UNSUCCESSFUL BIDDERS

ISSN 1727-3781

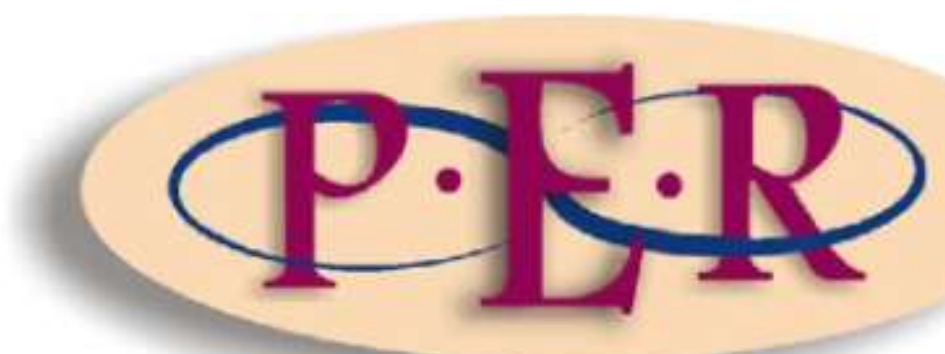

2010 VOLUME 13 No 3 


\section{MUNICIPAL TENDER AWARDS AND INTERNAL APPEALS BY UNSUCCESSFUL BIDDERS}

\section{P Bolton*}

\section{Introduction}

The Supreme Court of Appeal in CC Groenewald v M5 Developments ${ }^{1}$ recently held that the unsuccessful bidders in that case had a right, under Section 62 of the Local Government: Municipal Systems $A c t,{ }^{2}$ to appeal the municipality's decision to award a tender. The decision is particularly noteworthy because for some time now the application of Section 62 to tender processes has been a cause of disagreement. A number of cases have dealt with its application to municipal tender awards, sometimes with diverging results. This article will critically analyse the judgments in all these cases. Since the appeal authority in some of the cases was the accounting officer or municipal manager of the municipality, the article will also clarify the role of municipal managers in bid processes, and in particular, their role with respect to bid adjudication committees (BAC). Ultimately, the aim of the article is to demystify the application of Section 62 of the Municipal Systems Act to municipal tender awards. In doing so, regard will also be had to the dispute resolution procedures in place under the Municipal Supply Chain Management Regulations (hereafter the Supply Chain Management Regulations) ${ }^{3}$ enacted under the Local Government: Municipal Finance Management Act ${ }^{4}$ and their relation to Section 62 of the Municipal Systems Act.

First, a brief overview will be given of the bid committee system in place at local government level. Attention will then be given to the role that municipal managers play in bid processes, with particular reference to final awarding of a contract. A

\footnotetext{
* Phoebe Bolton. BProc LLB LLM LLD (UWC). Professor of Law, Stellenbosch University, South Africa (pbolton@sun.ac.za). This material is based upon work supported financially by the National Research Foundation.

1 (283/09) [2010] ZASCA 4731 March 2010 (hereafter CC Groenewald).

232 of 2000, as amended by Act 44 of 2003 (hereafter Municipal Systems Act).

3 Local Government: Municipal Finance Management Act (56/2003): Municipal Supply Chain Management Regulations GN 868 in GG 27636 of 30 May 2005.

456 of 2003 (hereafter Municipal Finance Management Act).
} 
distinction will be drawn between those instances in which the municipal manager makes the final award and those in which the BAC of the municipality has the power to make a final award. Next, the focus will fall on internal appeals against tender awards. Attention will be given to the applicable legislative provisions and more specifically the manner in which the courts have interpreted the provisions. Thereafter, the focus will be on the lodging of objections and complaints by unsuccessful bidders under the Supply Chain Regulations. The relevant parts of the Regulations will be analysed, as well as their relation to Section 62 of the Municipal Systems Act. Throughout the article, an attempt will be made to clarify the role of municipal managers in appeal and dispute resolution processes.

\section{The bid committee system ${ }^{5}$}

The Supply Chain Regulations, enacted under the Municipal Finance Management Act, stipulate that each municipality and each municipal entity must have and implement a supply chain management policy. ${ }^{6}$ Such policy must, inter alia, provide for a committee system for competitive bids consisting of at least a bid specification committee, a bid evaluation committee (BEC) and a BAC. ${ }^{7}$ The bid specification committee is responsible for the drafting of specifications, ${ }^{8}$ and evaluation of submitted tenders must take place by the BEC. ${ }^{9}$ The BEC must evaluate the tenders in accordance with the specifications for each procurement, as well as the applicable points system. It must evaluate the ability of each bidder to execute the contract and ensure that the recommended bidder's municipal rates and taxes and municipal service charges are not in arrears. The BEC must then submit a report and recommendations to the BAC for the award of the tender. A municipality's system of delegations generally determines whether it is the BAC or the municipal manager of the municipality who makes the final award. In particular, a distinction can be drawn between the following two scenarios.

5 The aim of this paragraph is to deal only with relevant aspects of the bid committee system. For detailed discussion and analysis, see Bolton 2009 PER 56-92. See also Steytler and De Visser Local Government Law 14-23 to 14-29.

6 Reg 2, read with S 111 of the Municipal Finance Management Act.

7 Reg 26.

8 Reg 27.

9 Reg 28. 


\section{$2.1 \quad$ The bid adjudication committee recommends a bidder}

In terms of the municipality's system of delegations the BAC, after having considered the report and recommendations of the $\mathrm{BEC}$, may be required to make a recommendation to the municipal manager for the award of a tender. ${ }^{10}$ Once the municipal manager receives a recommendation, he/she may do one of three things. Agreement with the recommendation of the BAC would usually mean that the municipal manager makes the final award. If, on the other hand, the municipal manager does not agree with the recommendation, he/she could refer the recommendation back to the $\mathrm{BAC}$ for reconsideration. Alternatively, the municipal manager could reject the BAC's recommendation and award the tender to another bidder. If the municipal manager awards the tender to a bidder other than the one recommended, he/she must in writing, within ten working days, notify the AuditorGeneral, the relevant provincial treasury and the National Treasury, and in the case of a municipal entity also the parent municipality, of the reasons for deviating from the decision of the BAC. ${ }^{11}$ The municipal manager has, however, no duty to report if he/she rejects the recommendation of the BAC in order to rectify an irregularity in the process. $^{12}$

\subsection{The bid adjudication committee makes a final award}

In terms of the municipality's system of delegations, the municipal manager may delegate the power to make the final award of a contract to the BAC. ${ }^{13}$ In other words, instead of making a recommendation to the municipal manager, the BAC may be delegated the power to make the final award. A question that arises is whether the municipal manager has the power to interfere with such award decision once made. In the light of the wording used in Regulation 29(6) of the Supply Chain Regulations, it would appear that the answer is in the negative. Regulation 29(6) provides that:

10 Supply Chain Reg 29(1)(b)(i).

11 Supply Chain Reg 29(7), read with S 114(1) Municipal Finance Management Act.

12 S 114(2) Municipal Finance Management Act.

13 Supply Chain Reg 29(1)(b)(i). 
[t]he accounting officer [municipal manager] may at any stage of a bidding process, refer any recommendation made by the evaluation committee or the adjudication committee back to that committee for reconsideration of the recommendation.

It could be argued that in a case in which the BAC made no "recommendation" but a final award, the municipal manager has no power under Regulation 29(6) to direct the BAC to reconsider the award. Regulation 29(6) makes specific reference to the making of a "recommendation". Reference is not made to an "award", that is, the final award of a tender by the BAC.

Regulation 5(3) of the Supply Chain Regulations does however require the BAC to submit a written report on each final award made during that month within five days after the end of the month, specifying the amount of the award, the name of the successful bidder and the reason for the decision. Depending on the municipality's hierarchical organogram, the BAC is required to report to the municipal manager if the chief financial officer or a senior manager is a member of the BAC. If the chief financial officer or a senior manager is not a member of the BAC, the BAC must report to the chief financial officer or the senior manager responsible for the tender. ${ }^{14}$

Regulation 38(1)(b) of the Supply Chain Regulations further stipulates that a municipality's supply chain management policy must enable the municipal manager to investigate any allegations against an official or other role-player of fraud, corruption, favouritism, unfair and irregular practices or a failure to comply with the supply chain management system of the municipality. The municipal manager must also be able, when justified, to take appropriate steps against an official or roleplayer, or report any alleged criminal conduct to the South African Police Service.

In the light of these provisions, therefore, it is possible for the municipal manager to interfere with the BAC's award decision, but only in cases in which allegations of fraud, corruption, favouritism, unfair and irregular practices or a failure to comply with the municipality's supply chain management system are made against an official or other role-player. Such interference may arguably take the form of suspension of the

14 Supply Chain Reg 5(4). 
award, conclusion of a contract and/or the implementation of a contract with the preferred bidder until such time that the investigation is complete.

\section{Internal appeals against awards: Section 62 of the Municipal Systems Act}

In recent years, there has been a significant increase in the number of judicial review applications that reach the courts. As recently pointed out by the Supreme Court of Appeal, the courts "are swamped with unsuccessful [bidders] that seek to have the award of contracts set aside and for the contracts to be awarded to them". ${ }^{15}$ Legislation does however make provision (also) for the internal resolution of disputes. In the local government context, it is particularly Section 62 of the Municipal Systems Act that has in recent times attracted attention. Section 62, in so far as is relevant for current purposes, provides as follows:

(1) A person whose rights are affected by a decision taken by a political structure, political office bearer, councillor or staff member of a municipality in terms of a power or duty delegated or sub-delegated by a delegating authority to the political structure, political office bearer, councillor or staff member, may appeal against that decision by giving written notice of the appeal and reasons to the municipal manager within 21 days of the date of the notification of the decision.

(2) The municipal manager must promptly submit the appeal to the appropriate appeal authority mentioned in subsection (4).

(3) The appeal authority must consider the appeal, and confirm, vary or revoke the decision, but no such variation or revocation of a decision may detract from any rights that may have accrued as a result of the decision.

(4) When the appeal is against a decision taken by-

(a) a staff member other than the municipal manager, the municipal manager is the appeal authority.

In the ensuing paragraphs, the above provision will be critically analysed. In particular, attention will be given to the nature of an appeal under Section 62, the accrual of rights under Section 62(3), the exercise of delegated powers under Section 62(1), and the exhaustion of internal remedies under the Promotion of Administrative Justice Act. $^{16}$

15 Moseme Road Construction CC v King Civil Engineering Contractors (Pty) Ltd (385/2009) [2010] ZASCA 1315 March 2010.

163 of 2000 (hereafter PAJA). 


\subsection{The nature of an appeal under Section 62}

As a rule, and in the context of tender processes, the municipal manager of the municipality is the appeal authority for purposes of Section $62 .{ }^{17}$ The role of the municipal manager as appeal authority under Section 62 should however be distinguished from the role he/she plays during the bid process itself, that is, the process that precedes an appeal. As will be explained below with reference to the case of CC Groenewald, the nature of an appeal under Section 62 and the powers afforded under the provision differ from the general supervisory powers afforded to the municipal manager over bid committees.

\subsubsection{The facts in CC Groenewald}

In this case, the municipality invited tenders for the appointment of an "implementation agent" for housing projects. The municipality received a number of tenders, but only five of these were considered acceptable. The municipality appointed a firm of consulting engineers to evaluate these tenders and it recommended the award of the tender to M5 Developments (Cape) (Pty) Ltd (M5), since it scored the highest points. The second highest bidder was Asla Devco (Pty) Ltd (Asla) with a slightly lower score and the other three bidders scored lower points, with Blue Whale Property CC (Blue Whale) scoring the lowest points. The BEC accepted the recommendation of the consulting engineers and on recommending M5 to the BAC the latter decided to award the tender to M5.

M5 was informed of the success of its tender and the four unsuccessful bidders were similarly informed of the outcome and that they had 21 days to lodge an appeal under Section 62 of the Municipal Systems Act. Two of the unsuccessful bidders (Blue Whale and Asla) lodged appeals. Only Blue Whale however lodged its appeal in time, and was considered by the municipal manager who acted as appeal authority. Based on the facts disclosed in the judgment, it would appear that in terms of the municipality's system of delegations, it was the BAC that had the power to

17 In terms of Supply Chain Reg 29(1)(b)(i), the municipal manager of the municipality has the final power of approval, read with S 60 of the Municipal Finance Management Act, which describes the municipal manager as "accounting officer" of the municipality. 
make the final decision regarding the award of the tender. ${ }^{18}$ In other words, the BAC did not make (or was not required to make) a "recommendation" to the municipal manager and the municipal manager did not make the final award.

In dealing with the appeals, the municipal manager was of the view that Asla's appeal could not be considered as it was out of time. Blue Whale's appeal, on the other hand, was without merit, as it had no prospect of success; it scored the lowest points. Instead of dismissing Blue Whale's appeal, however, the municipal manager re-evaluated the tenders submitted. In doing so, he concluded that both the consulting engineers and the BEC had incorrectly scored the tenders. He hence approached M5 and Asla requesting the provision of further information to him by a certain date. Asla responded in time, but M5, in spite of an extension of the due date did not respond. M5 requested a further extension, but the municipal manager declined. Based upon the new information received from Asla, the municipal manager recalculated the points scored and decided that the tender should not have been awarded to M5 but to Asla, since Asla scored the highest points according to his recalculation.

M5 successfully took the matter on review. The Western Cape High Court (Cape Town) set aside the municipal manager's decision to award the contract to Asla and held that M5 "is entitled to enter into a contract with [the municipality] pursuant to the allocation of [the] tender". ${ }^{19}$ It is with leave of the court that the municipal manager, the municipality and Asla appealed to the Supreme Court of Appeal, arguing that the review ought to have been dismissed.

\subsubsection{The arguments and judgment}

The Supreme Court of Appeal in essence confirmed the lower court's decision. On appeal, and in the lower court, it was M5's submission, which it subsequently conceded to during the appeal, that an unsuccessful bidder such as Asla does not have clearly defined rights that were adversely affected by the decision of the BAC.

18 Para 10 CC Groenewald.

19 Para 54 M5 Developments (Cape) (Pty) Ltd v CC Groenewald Case 6277/08 [2009] ZAWCHC 3 12 February 2009. 
With reference to the decision in Municipality of the City of Cape Town $v$ Reader, ${ }^{20}$ it was argued that an unsuccessful bidder has no right to appeal under Section 62 of the Municipal Systems Act.

The Supreme Court of Appeal drew a distinction between the case at hand and the case of Reader. In the latter case, the court noted, the decision was based on the reasoning that "a neighbour could not be considered as a person whose rights were affected by the municipality's decision in regard to building plans approved for a neighbouring property as it had not been a party to the application process relating to those plans". 21 In the present case, however, the unsuccessful bidders were all parties to the tender approval process and hence had a right to appeal under Section 62.

The remaining issue was whether the municipal manager of the municipality, as appeal authority, was entitled to award the tender to an unsuccessful bidder who was not a party to the appeal. It was argued on behalf of the municipal manager (and the other appellants) that an appeal under Section 62 of the Municipal Systems Act is a "wide appeal". In rehearing the issues, the municipal manager was entitled to award the tender to the party who should have been awarded the tender in the first place, even if that party was not a party to the appeal. ${ }^{22}$

The court agreed that an appeal under Section 62 of the Municipal Systems Act is a "wide appeal" involving a re-hearing of the issues, but held that Section 62 does not allow the appeal authority to revisit all the tenders and to award the tender to an unsuccessful bidder who did not appeal or, as in this case, whose appeal was out of time. The court referred to the wording of Section 62 and held that:

[s]ection 62(1) allows a person to appeal by giving 'written notice of the appeal and reasons' to the municipal manager who, under s 62(2) has then to submit 'the appeal' - obviously the notice of appeal and the reasons lodged therewith under s 62(1) - to the appeal authority for it to consider 'the appeal' under s 62(3). Although in terms of this latter subsection the appeal authority is empowered to 'confirm, vary or revoke the decision' it exercises

2020091 SA 555 (SCA) - hereafter Reader.

21 Para 21 Reader.

22 Para 23 CC Groenewald. 
that power in the context of hearing 'the appeal' viz the appeal and the reasons lodged by the aggrieved person under $s$ 62(1). That defines the ambit of the appeal, the sole issue being whether that aggrieved person should succeed for the reasons it has advanced. ${ }^{23}$

The court concluded that in this case the appeal related only to whether the tender should have been awarded to Blue Whale as opposed to M5. Once the municipal manager was of the view that Blue Whale's appeal was without merit and having dismissed Asla's appeal, the only course of action was to dismiss Blue Whale's appeal. He was not entitled to re-evaluate and re-allocate the tender as he did.

In response to the suggestion by the appellants that should the court find that the municipal manager had no power to award the contract to Asla, the court should refer the matter back to the BAC for reconsideration, the court found that there was no merit in this suggestion. The municipal manager, as appeal authority, had the power under Section 62(3) of the Municipal Systems Act to "consider the appeal, and confirm, vary or revoke the decision". He had no power to refer the matter back to the BAC for reconsideration. This being so, the court is also not in a position to make an order on review that the municipal manager could not have made. ${ }^{24}$

It is clear therefore that the nature of an appeal under Section 62 and the powers afforded to the municipal manager under the provision differ from the general supervisory powers of the municipal manager over bid committees. It is, for example, only in a case in which the BAC is required, by the system of delegations in place in the municipality, to make a "recommendation" to the municipal manager for the award of a tender that he/she has a choice whether to award the tender to a different bidder or to refer the matter back to the BAC for reconsideration should he/she not agree with the recommendation. Should the system of delegations allow the BAC to make the final award, the municipal manager's interference in the award may be confined to instances in which allegations of fraud, corruption, favouritism, unfair and irregular practices or a failure to comply with the municipality's supply chain management policy are made against an official or other role-player. When the municipal manager acts as appeal authority under Section 62 of the Municipal

23 Para 24 CC Groenewald.

24 Para 27 CC Groenewald. 
Systems Act, he/she is confined to the subject matter of the appeal. He/she is not at liberty to revisit all the tenders and to award the tender to a bidder who is not a party to the appeal. On finding that an appeal is without merit, he/she must dismiss the appeal and is not in a position to refer the matter back to the BAC for reconsideration.

\subsection{The accrual of rights under Section 62(3)}

Section 62(3) of the Municipal Systems Act provides that once an appeal is lodged and referred to the appropriate appeal authority, the latter "must consider the appeal, and confirm, vary or revoke the decision, but no such variation or revocation of a decision may detract from any rights that may have accrued as a result of the decision". This subsection has given rise to some debate and will be discussed with reference to the Western High Court (Cape Town) decision in Loghdey $v$ Advanced Parking Solutions $C$. $^{25}$

3.2.1 The facts, arguments and judgment in Loghdey $\mathrm{v}$ Advanced Parking Solutions

In this case, the municipality's BAC awarded a tender to Loghdey (the applicant) for a kerbside parking management service and soon after a formal contract was concluded. Advanced Parking Solutions, the first respondent and an unsuccessful bidder, appealed against the award, relying on Section 62 of the Municipal Systems Act. At first, the municipality took the view that no appeal was available and informed both Loghdey and Advanced Parking Solutions of this. Subsequently, however, the municipality decided to hear the appeal. After the appeal proceedings had been postponed on two occasions, Loghdey approached the court for an order that no appeal was available.

Loghdey argued that because rights had already accrued to it because of the unconditional award of the tender to it, as well as the subsequent conclusion of a formal contract, Section 62(3) of the Municipal Systems Act applied, which precluded

25 Case 20766/2008 (W) 25 February 2009 (unreported). 
an appeal under Section $62 .^{26}$ Advanced Parking Solutions countered that the municipality's tender invitation made the award of the contract subject to a 21-day appeal period and that the municipality's own supply chain management policy stipulated that tender awards may only be made once any appeals have been satisfactorily resolved. ${ }^{27}$

The court found in favour of Loghdey. It held that even though the bid conditions and the municipality's supply chain management policy both made provision for an appeal process, they did not provide for a right of appeal. They simply created an obligation that participating bidders be informed of their right to appeal a tender award. ${ }^{28}$ The court found that since neither the notification of the tender award to Loghdey nor the formal contract concluded with it made the award or the conclusion of the contract conditional upon an appeal period, unconditional rights vested in Loghdey following the award of the tender and the conclusion of the contract. Section 62(3) of the Municipal Systems Act was, accordingly, of application with the result that while an appeal under Section 62(1) of the Act was possible, Section $62(3)$ rendered the appeal nugatory. ${ }^{29}$

The court further distinguished the case at hand from the judgment in Syntell (Pty) Ltd $v$ The City of Cape Town ${ }^{30}$ and held that while the facts in Syntell were very similar, the primary difference was that the notification of the tender award in Syntell expressly stated that the award was subject to a 21-day appeal period, and that no rights would accrue before the expiry of that period. In the case at hand, the court held, the notification contained no such statement. ${ }^{31}$ The court also noted that even had the municipality acted incorrectly in its failure to notify unsuccessful bidders of their right of appeal and the signing of the contract with Loghdey was legally flawed, the contract remained valid and enforceable until it was set aside by a court of law. ${ }^{32}$

26 Para 15 Loghdey.

27 Para 16 Loghdey.

28 Para 27-31 Loghdey.

29 Para 33 Loghdey. See also Robcon Civils/Sinawamandla 2 Joint Venture v Kouga Municipality 20103 SA 241 (ECP) para 17 (hereafter Robcon Civils/Sinawamandla 2 Joint Venture).

30 Case 17780/07 (CPD) [2008] ZAWCHC 12013 March 2008 (unreported) - hereafter Syntell.

31 Para 32 Syntell.

32 Para 34 - referring to Oudekraal Estates (Pty) Ltd v City of Cape Town 20046 SA 222 241, para 26. 
Recently, the court in Mohammed Zunade Loghdey $v$ City of Cape Town ${ }^{33}$ confirmed, although expressing reservations about Section 62 and the manner in which the provision is drafted, that Advanced Parking Solutions (and another unsuccessful bidder by the name of Numque) did not, on an interpretation of Section 62 and with reference to the Supreme Court of Appeal decision in Reader, have a right of appeal. ${ }^{34}$ The court dismissed Loghdey's main application for an order directing the municipality to implement the contract concluded with it. In short, Loghdey's tender did not comply with the technical specifications and some of the pre-qualification criteria of the tender. ${ }^{35}$ On the question of whether the counterapplication brought by Advanced Parking Solutions and Numque should have been entertained by the court, considering the lateness of their application for review, the court held that there were justifiable reasons for the delay ${ }^{36}$ and granted an order extending the period within which the parties might institute proceedings for the judicial review and setting aside of the municipality's decision to accept Loghdey's tender and to conclude a contract with it. The court set aside the municipality's decision to accept Loghdey's tender and to conclude a contract with it.

It is important to note that the facts in Loghdey $v$ Advanced Parking Solutions can be distinguished from those in CC Groenewald discussed earlier. ${ }^{37}$ Based on the facts in CC Groenewald, which are similar to the facts in Syntell, no rights had accrued under Section 62(3) of the Municipal Systems Act to the preferred bidder (M5) at the time of the appeal. The municipality had not concluded a contract with M5 and the unsuccessful bidders were specifically informed of their right to appeal the award decision under Section 62 of the Municipal Systems Act. These facts in all probability explain why the court in $C C$ Groenewald did not consider the consequences of an accrual of rights under Section 62(3) of the Municipal Systems Act.

33 Mohammed Zunade Loghdey $v$ City of Cape Town; Advanced Parking Solutions CC $v$ City of Cape Town Case 100/09 [2010] ZAWCHC 25, 20 January 2010 (hereafter Mohammed Zunade Loghdey).

34 See paras 23-36 Mohammed Zunade Loghdey and more specifically para 35.

35 Paras 41 and 55 Mohammed Zunade Loghdey.

36 Para 62 Mohammed Zunade Loghdey.

37 S 3.1.1 and 3.1.2. 


\subsection{The exercise of delegated powers under Section 62(1) and the exhaustion of internal remedies under the Promotion of} Administrative Justice Act

The application of Section 62 to municipal tender awards was raised as a preliminary point in Lohan Civil-Tebogo Joint Venture $v$ Mangaung Plaaslike Munisipaliteit. ${ }^{38}$ Interesting points were further made on the requirement in the PAJA that an applicant for review is required to exhaust all internal remedies available to it before instituting judicial review proceedings. All these points are discussed below.

\subsubsection{The facts in Lohan Civil-Tebogo Joint Venture}

In this case, the municipality called for tenders in respect of certain road works. A firm of consulting engineers evaluated the tenders and recommended that only three bidders (Lohan, Moeletsi and Tau Pele) had the necessary capacity and experience to complete the project and were considered of low risk. In particular, Lohan was identified as preferred bidder, with Moeletsi second and Tau Pele third. The BEC of the municipality agreed with the scoring of the bidders and recommended Lohan as preferred bidder to the BAC. The BAC, however, disagreed with the recommendation and referred it back to the BEC for reconsideration. The BEC again recommended Lohan but, despite the recommendation, the BAC recommended Moeletsi to the municipal manager, who approved the recommendation. ${ }^{39}$

\subsubsection{The arguments and judgment}

Lohan (and other interested parties) felt aggrieved by the award of the tender to Moeletsi and approached the court for an interim interdict to prevent the execution of the tender pending the finalisation of a review application setting aside the award of the tender and contract to Moeletsi. The municipality (and the other respondents), however, raised a preliminary point. It was argued that in terms of Section 7(2)(a) of PAJA, a review application cannot succeed unless the court is satisfied that an

38 Case 508/2009 (O) [2009] ZAFSHC 2127 February 2009 (unreported) - hereafter Lohan.

39 Paras 5-11 Lohan. 
applicant has exhausted internal remedies available to it. Reliance was placed on the Nichol case ${ }^{40}$ and it was argued that Lohan had the following remedies available:

1. The appeal procedure provided for in section 62 of the Municipal Systems Act.

2. The conditions of tender contained a procedure for objections and complaints to be lodged with the municipal manager within 14 days.

3. Regulation 50 of the Supply Chain Regulations provided that the supply chain management policy of a municipality must set out a dispute resolution procedure and the municipality's policy did in fact provide for such a procedure [this point was raised by the court mero motu].

The court held that it is true that Section 7(2)(a) of PAJA provides for the exhaustion of internal remedies prior to the institution of review proceedings, but on a purely grammatical interpretation of the provision, the prohibition is only relevant for the purposes of a full review and not an application for interim relief. The court held that the intention of the legislature was to prohibit a review application being heard and decided before internal remedies had been exhausted, and not the award of interim relief. Despite reaching this conclusion, however, the court proceeded to consider the remedies referred to and whether they constituted internal remedies for the purposes of Section 7(2) of PAJA. ${ }^{41}$

\subsubsection{An appeal under Section 62}

With respect to the availability of an appeal under Section 62 of the Municipal Systems Act, the court held that on the language of Section 62(1), it is clear that it envisages an appeal against a decision that was taken pursuant to a delegation of authority. In the present case, the decision to award the tender to Moeletsi was ratified by the municipal manager who was not exercising a delegated power, but an original power. In terms of Regulation 29(5)(b)(i) of the Supply Chain Regulations, the municipal manager of the municipality has the final power of approval read with Section 60 of the Municipal Finance Management Act, which describes the municipal manager as "accounting officer" of the municipality. An appeal under Section 62 of the Municipal Systems Act was, accordingly, not available to Lohan. ${ }^{42}$

40 Nichol v Registrar of Pension Funds 20081 SA 383 (SCA) 390A.

41 Paras 18-23 Lohan.

42 Paras 24-27 Lohan. 
The court (mero motu) considered also the application of Section 62(3) of the Municipal Systems Act to the facts at hand. In this regard, the court held that after the award of the tender to Moeletsi and the subsequent conclusion of a contract between it and the municipality, rights accrued to Moeletsi, which under Section 62(3) of the Municipal Systems Act could not be disturbed on appeal. The court relied on and approved of the decision in Reader $v$ lkin, ${ }^{43}$ in which it was held that the effect of Section 62(3) is that once a right accrues as a result of the decision, such decision cannot on appeal be reversed if it would have the effect of taking away a right initially granted. Section 62 , and specifically with reference to Section 62(3) was, accordingly, not a viable remedy for Lohan. ${ }^{44}$

\subsubsection{An appeal to the municipal manager}

With respect to the remedy of an appeal to the municipal manager based on the terms of the conditions of tender, the court held that the procedure provides for a complaint and objection to be lodged with the municipality against a decision of the municipality itself. Logic dictates that this is not at all an effective remedy. ${ }^{45}$

\subsubsection{Procedure under the municipality's supply chain management policy}

On the availability of a procedure under the supply chain management policy of the municipality for the resolution of disputes, the court noted that such procedure was aimed at the settlement of disputes. The person appointed to deal with disputes did not have any power to enforce an effective remedy. In this respect, the court relied on the judgment in Reed, ${ }^{46}$ in which it was held that inherent in the concept of a "remedy", as is used in a legal context, is the notion that in order for a "procedure" to qualify as a remedy, it must be capable of providing, in law, what the Constitution terms an "effective remedy". Section 7(2) of PAJA does not place an obligation on an aggrieved party to exhaust all possible sources of redress in the political or administrative system prior to resorting to judicial review. An "internal remedy" as

43 Reader v lkin 20082 SA 582 (CPD) 587D-590G.

44 Paras 28-29 Lohan.

45 Para 30 Lohan.

46 Reed $v$ Master of the High Court of SA [2005] 2 All SA 429 (E) 436A-F. 
used and understood in the field of administrative law is used in a specialised context. It connotes an administrative appeal, usually on the merits to an official or tribunal within the same administrative hierarchy as the initial decision-maker, or an internal review. Often the appellate body will be more senior and experienced. Before a so-called internal remedy can qualify as such (for the purposes of Section 7(2) of PAJA) it would have to provide a prejudiced party with an effective remedy. The court concluded that the procedure set out in the municipality's supply chain management policy clearly does not measure up to this standard and therefore does not qualify as an internal remedy. ${ }^{47}$

Lohan was, accordingly, not affected by the prohibition contained in Section 7(2) of PAJA, which requires an applicant to exhaust all internal remedies before instituting a review application. There was no internal remedy available to Lohan, which it was required to use before initiating review proceedings. The preliminary point therefore failed. ${ }^{48}$

\section{Objections and complaints under the Supply Chain Regulations}

It is important to note that whereas Section 62 of the Municipal Systems Act is a general appeal provision, the Supply Chain Regulations, enacted under the Municipal Finance Management Act, make specific provision for the internal resolution of disputes. Regulation 49 stipulates that a municipality's supply chain management policy must allow persons aggrieved by decisions or actions taken in the implementation of a municipality or municipal entity's supply chain management system, to lodge a written objection or complaint against the decision or action within 14 days. A supply chain management policy must, in terms of Regulation 50(1), provide for the appointment of:

an independent and impartial person not directly involved in the supply chain management processes of the municipality or municipal entity -

(a) to assist in the resolution of disputes between the municipality or municipal entity and other persons regarding -

47 Paras 31-33 Lohan.

48 Para 34 Lohan. 
(i) any decisions or actions taken by the municipality or municipal entity in the implementation of its supply chain management system; or

(ii) any matter arising from a contract awarded in the course of its supply chain management system; or

(b) to deal with objections, complaints or queries regarding any such decisions or actions or any matters arising from such contract.

The accounting officer (municipal manager) or an official designated by him or her must assist the person appointed to ensure that his or her functions are performed effectively. The appointed person must also strive to resolve all disputes, objections, complaints or queries received promptly and must report to the accounting officer on disputes received, attended to and resolved on a monthly basis. If, after sixty days, the dispute remains unresolved, or the municipality or municipal entity provides no response, the dispute may be referred to the relevant provincial treasury. If the latter cannot resolve the dispute, it may be referred to the National Treasury for resolution. A person affected is however entitled to approach a court of law at any time for the resolution of the dispute. ${ }^{49}$

In the light of the above provisions, it is clear that the person who is required to deal with disputes should be "independent and impartial", and he/she should not be "directly involved in the [municipality's] supply chain management processes". It stands to reason therefore that even though the municipal manager of the municipality (or an official designated by him or her) is required to "assist" the person appointed to ensure the effective performance or his or her functions, it is not permissible for the municipal manager to perform the functions himself or herself. A question further arises with respect to the relation between dispute resolution procedures under the Supply Chain Regulations, and the appeal process provided for in Section 62 of the Municipal Systems Act. This will be discussed in turn.

\subsection{The relation between Section 62 of the Municipal Systems Act and dispute resolution under the Supply Chain Regulations}

As alluded to earlier, there are significant differences between Section 62 of the Municipal Systems Act and the relevant Supply Chain Regulations. Whereas Section

49 Supply Chain Reg 50(3)-50(7). 
62 is a general appeal provision and not specific to supply chain management or municipal tenders, the Regulations discussed apply within the context of supply chain management and tender processes. Section 62 further qualifies as an internal remedy for the purposes of Section 7(2) of PAJA, whereas the applicable Regulations do not give rise to an internal remedy as referred to in Section 7(2) of PAJA. The Regulations only refer to the resolution of objections and complaints. On a reading of the Regulations, there is no intention on the part of the legislature for the independent and impartial third party to have remedial powers. He/she is simply required to resolve or settle complaints and objections. On the wording of the Regulations, a municipality or municipal entity is under an obligation to provide for the filing of objections and complaints, but remedies are not the outcome of these as such.

Section 62 of the Municipal Systems Act further provides bidders, in appropriate cases, twenty-one days within which to file an appeal, whereas the Supply Chain Regulations only allow for a 14-day period for the lodging of complaints and objections. Moreover, the Regulations specifically state that a person affected is entitled to approach a court of law for the resolution of the dispute at any time.${ }^{50}$ An aggrieved party is, in other words, not required to exhaust the dispute resolution procedures provided for in the Regulations first. Section 7 of PAJA, which deals with the procedure for judicial review, provides that a court or tribunal shall not review an administrative action unless any internal remedy provided for in any other law has first been exhausted. If a court or tribunal finds that an internal remedy has not been exhausted, it must direct the person concerned to exhaust such internal remedy before instituting review proceedings. Only in exceptional circumstances, and on application by the person concerned, may a court or tribunal exempt a person from the obligation to exhaust an internal remedy if this is deemed to be in the interests of justice. ${ }^{51}$ In the light of the wording of the Supply Chain Regulations, therefore, it is clear that Section 7 of PAJA will not find application. The Regulations expressly provide that a person affected may dispense with the use of internal procedures at any time and approach a court of law for the resolution of the dispute.

50 Supply Chain Reg 50(7).

51 S 7(2) PAJA. 
Section 7 of PAJA would however find application with reference to Section 62 of the Municipal Systems Act in a case in which an award decision was exercised under a delegated power and no rights had accrued to the preferred bidder at the time of the appeal. Therefore, were an unsuccessful bidder to file a review application under PAJA in a case in which it was possible for such bidder to have recourse to Section 62 of the Municipal Systems Act, the court is likely to find, in the absence of exceptional circumstances, that the unsuccessful bidder failed to first exhaust an internal remedy available to it. ${ }^{52}$

In Mohammed Zunade Loghdey, Binns Ward J was of the view that the procedure for lodging objections and complaints under the Supply Chain Regulations should be distinguished from the right of an unsuccessful bidder to appeal under Section 62 of the Municipal Systems Act. It was noted that the Supply Chain Regulations "[refer] to objections and complaints not appeals: and secondly, it affords a time period for the lodging of such complaints or objections which is different from that allowed by the Systems Act for the lodging of appeals". ${ }^{53}$ The court further noted that:

[t]o the extent that the judgment in Total Computer Services (Pty) Ltd $v$ Municipal Manager, Potchefstroom Local Municipality 2008 (4) SA 346 (T) at paras [65]-[74] appears to hold differently, I respectfully differ. The case in Total Computer Services appears in any event to have proceeded on the basis of an acceptance that an appeal in terms of s 62 of the Systems Act was available ex lege to an unsuccessful [bidder]. ${ }^{54}$

In the light of the court's view, the decision in Total Computer Services ${ }^{55}$ requires further discussion.

\subsection{The facts, arguments and judgment in Total Computer Services}

In this case, the municipality called for tenders for the provision and implementation of a system to process and enforce road traffic violations within its municipal area. The municipality received a number of tenders, and the BEC and the BAC

52 Koyabe v Minister for Home Affairs Case CCT 53/08 [2009] ZACC 23.

53 Mohammed Zunade Loghdey at footnote 19.

54 Mohammed Zunade Loghdey at footnote 19.

55 Total Computer Services (Pty) Ltd v Municipal Manager, Potchefstroom Local Municipality 2008 4 SA $346(T)$ - hereafter Total Computer Services. 
recommended the award of the tender to Inyanga. The municipal manager approved the recommendation and made the final award. After being notified of the award, however, the applicant Total Computer Services (Pty) Ltd (TCS), an unsuccessful bidder, lodged an appeal with the municipality. This was done approximately 20 days after the notification. The municipality dismissed the appeal as out of time, reasoning that Regulation 49 of the Supply Chain Regulations restricts appeals to a 14-day period and that this period had passed. The municipality and Inyanga then concluded a contract. ${ }^{56}$

Total Computer Services applied to court for the review and setting aside of the award. In particular, TCS argued that the award of the tender to Inyanga was made prematurely because the municipality failed to comply with its internal appeal process allowing for a 21-day appeal period. Clause 49 of the municipality's Procurement Policy stipulates that "[t]he written notification [of the decision to accept a bid] ... shall inform the parties ... of their right to appeal such decision within 21 days of the written notification of that decision in terms of $s 62$ of the [Municipal] Systems Act". ${ }^{57}$ Total Computer Services argued that the municipality acted improperly and unfairly by rejecting its appeal.

In essence, the municipality and TCS disagreed on whether a 21-day or a 14-day appeal period applied. ${ }^{58}$ The municipality argued that the 14-day period under the Supply Chain Regulations had to prevail over the ostensibly conflicting 21-day period under its own Procurement Policy and as set out in Section 62 of the Municipal Systems Act. The municipality based its argument on Section 3(2) of the Municipal Finance Management Act, which stipulates that "[i]n the event of any inconsistency between a provision of this Act and any other legislation in force when this Act takes effect and which regulates any aspect of the fiscal and financial affairs of municipalities or municipal entities, the provision of this Act prevails". The municipality was, in other words, of the view that the Supply Chain Regulations, enacted under the Municipal Finance Management Act, had to prevail over the conflicting provisions in its own Procurement Policy and the Municipal Systems Act.

56 Paras 8-12 Total Computer Services.

57 Para 28 Total Computer Services.

58 Para 34 Total Computer Services. 
On the question of whether the municipality correctly dismissed TCS's appeal as being out of time, the court referred to Clause 49 of the municipality's Procurement Policy that allows for a 21-day appeal period, such period being derived from Section 62 of the Municipal Systems Act, and the municipality's reliance on Regulation 49 of the Supply Chain Regulations, which allow for a 14-day period to lodge a complaint. ${ }^{59}$ In doing so, the court was of the view that before concluding that, with reference to Section 3(2) of the Municipal Finance Management Act, Regulation 49 of the Supply Chain Regulations trumps Clause 49 of the municipality's Procurement Policy allowing for a longer appeal period, whether there is an irreconcilable conflict between Regulation 49 and Clause 49 needs to be determined.

The court came to the conclusion that there was not an irreconcilable conflict. The court reasoned that the municipality chose to adopt a time period that went beyond the minimum time period prescribed in Regulation 49. In doing so, participating bidders had a legitimate expectation that the tender in question would be awarded in accordance with the time period stipulated in the municipality's Procurement Policy. ${ }^{60}$ The award of the tender to Inyanga was accordingly premature. The municipality should have allowed the 21-day period to pass and only thereafter made a final award of the tender. The court set aside the award and referred the matter back to the municipality for reconsideration in accordance with its Procurement Policy, applicable legislation and Section 217 of the Constitution.

Most relevant for current purposes is that the court (as well as the parties involved) appears to have been of the view that Regulation 49 of the Supply Chain Regulations and Section 62 of the Municipal Systems Act both allow for the filing of an internal "appeal". ${ }^{61}$ As explained earlier, there are significant differences between the two provisions. Most importantly, whereas Section 62 of the Municipal Systems Act is a proper "appeal" provision, Regulation 49 only provides for the lodging of complaints and objections without providing for any enforcement mechanism.

59 Paras 66-69 Total Computer Services.

60 Paras 71-72 Total Computer Services.

61 See, in particular, paras 62-74 Total Computer Services where the word "appeal" is used interchangeably. 
The court further appears to have proceeded on the basis that an appeal under Section 62 of the Municipal Systems Act is, as also noted by Binns Ward $J$ in Mohammed Zunade Loghdey, available to an unsuccessful bidder by operation of law. As already noted, an appeal under Section 62 is strictly confined. Section 62 applies only to the exercise of delegated powers and is of little assistance to an unsuccessful bidder in a case in which rights had already accrued to the successful bidder and which would be disturbed on appeal. On the facts in Total Computer Services, the municipal manager and not the BAC made the final award of the tender. As such, an appeal under Section 62 would in any event not have been available to TCS, as the provision only applies to the exercise of delegated powers.

Moreover, the court in Total Computer Services considered only the question of an irreconcilable conflict between Clause 49 of the municipality's Procurement Policy and Regulation 49 of the Supply Chain Regulations. No consideration was given to the question of a conflict between Clause 49 of the municipality's Procurement Policy and Regulation 49 of the Supply Chain Regulations, on the one hand, and Section 62 of the Municipal Systems Act, on the other hand. The question has accordingly been raised "whether a period for lodging appeals shorter than 21 days (but longer than 14) in a municipality's procurement policy would prevent an unsuccessful [bidder] from lodging an internal appeal specifically in terms of $s 62$ of the [Municipal] Systems Act after such shorter period had expired, but within the 21 -day period". 62 It is submitted that in the light of the arguments already made, an appeal under Section 62 of the Municipal Systems Act would be possible.

\section{Conclusion}

Section 62 of the Municipal Systems Act makes provision for the filing of appeals. In tender cases, however, the usefulness of this appeal process is particularly constrained. An unsuccessful bidder is, in principle, entitled to appeal a municipal tender award made by the BAC of the municipality under Section 62, but Section 62(3) will render such appeal nugatory had rights already accrued to the preferred bidder and such rights will be disturbed on appeal. This will be the case should an

62 See Quinot 2008 JQR para 2.3. 
unconditional award have been made or an unconditional contract been concluded with the preferred bidder. The only recourse then is for an unsuccessful bidder to apply for the judicial review of the tender award and/or the conclusion of the contract.

Further, if an appeal under Section 62 is possible, in the sense that the award of a tender and/or the conclusion of a contract with the preferred bidder was made subject to possible appeals, the appeal authority is confined to the subject matter of the appeal. The appeal authority has no power to revisit all the tenders and to award the tender to a bidder who did not appeal or who perhaps did appeal but whose appeal was out of time. Should the appeal authority further find that the appeal under consideration is without merit, the only course of action available is to dismiss the appeal. The matter cannot be referred back to the BAC, for example, for reconsideration. Appeals under Section 62 must, moreover, be brought within 21 days after the notification of the outcome of the award.

Juxtaposed to Section 62 of the Municipal Systems Act, the Supply Chain Regulations, enacted under the Municipal Finance Management Act, make provision for the lodging of objections or complaints by unsuccessful bidders. The Supply Chain Regulations stipulate that a municipality's supply chain management policy must make provision for the internal resolution of disputes by an independent and impartial third party. Provision should be made for unsuccessful bidders to lodge their complaints or objections within 14 days after the notification of the outcome of the award. This time period of course differs from the time period in Section 62 of the Municipal Systems Act, which allows for a 21-day period. Whereas Section 62 moreover refers to the filing of an "appeal", the Supply Chain Regulations simply refer to the lodging of "complaints and objections". It could hence be argued that the legislature intended different functions to be served by the two pieces of legislation and the applicable provisions.

Whereas Section 62, for example, is relatively clear on the procedures to be followed during an appeal process, the Supply Chain Regulations are not. The Supply Chain Regulations are, for example, silent on the nature of the power of the independent and impartial third party with respect to "interfering" with the award decision. It is not clear whether the legislature intended for the third party to be able to revisit all the 
tenders received and to award the tender to a different bidder, or whether the third party is entitled to refer the matter back to the relevant authority, for example the BAC, for reconsideration.

Unlike the Supply Chain Regulations, Section 62 of the Municipal Systems Act further makes specific reference to an appeal against the exercise of a delegated or sub-delegated power. Section 62 can, in other words, not be relied on if the award was made under an original power. Thus, it is only, for example, in the case in which the making of the final award is delegated by the municipal manager, who has original award-making powers, to the BAC that an appeal against an award by the BAC can take place under Section 62. If the municipal manager made the final award, an unsuccessful bidder cannot have recourse to Section 62, since the municipal manager will have acted under an original power. Under the Supply Chain Regulations, on the other hand, it would appear that objections and complaints can be lodged against an award decision made by the BAC or the municipal manager, as no reference is made to the exercise of "delegated" or "original" powers.

Some may argue that the application of Section 62 is not suitable to tender disputes, considering that an appeal is nugatory under this provision once rights have accrued to the preferred bidder. It is only when no rights have accrued to the preferred bidder that Section 62 can provide an unsuccessful bidder with a viable remedy. It would appear then that municipalities are the ones left with the power to determine whether they wish to be "bogged down" by the application of Section 62 to their tender decisions. They could effectively prevent Section 62 from having any application to their tender awards by making unconditional awards and/or concluding unconditional contracts with the result that rights will have accrued to the preferred bidder, which cannot be disturbed by an appeal under Section 62 .

The question then is whether municipalities are or should be under an obligation or duty bound to make tender awards that are conditional on a 21-day period, allowing unsuccessful bidders to appeal against the award decision. In the light of the wording used in Section 62 of the Municipal Systems Act, which is a general appeal provision and not strictly confined to municipal tender processes, municipalities are not duty bound to make conditional awards. The Supply Chain Regulations, on the other 
hand, do make clear that municipalities "must" make provision in their supply chain management policies for the lodging of "complaints and objections" within a 14-day period after the outcome of a tender process. As noted, however, the legislature is not clear on the extent of the powers of the independent and impartial third party in charge of considering the objections and complaints. It is not clear to what extent he/she may be able to interfere in the award decision made, that is, whether he/she may decide to award the tender to a different bidder or refer the matter back to the BAC for reconsideration.

It is submitted that in order to comply with the constitutional requirements governing municipal tender processes (that is fairness, equity, transparency, competitiveness and cost-effectiveness), ${ }^{63}$ it is necessary for legislation at local government level (and also at national and provincial government level) to provide for internal dispute resolution procedures more effectively. As it stands currently, unsuccessful bidders are inadequately protected and in most cases can only seek to protect and enforce their rights by means of costly litigation.

It is clear, however, that the courts frown upon municipalities that show a flagrant disregard for the rights of bidders in tender processes. Recently, the court in Robcon Civils/Sinawamandla 2 Joint Venture ordered the municipality to pay the legal costs of an aggrieved bidder who was told that it had to use the Promotion of Access to Information $\mathrm{Act}^{64}$ to obtain documents it needed to lodge an internal appeal. In short, the bidder proved to the court that it had notified the municipality of its intention to appeal the award decision under Section 62 of the Municipal Systems Act. The municipality however disregarded such notification, which included a request for information pertaining to the award decision to facilitate an appeal by the bidder, and proceeded to conclude a contract with another bidder. Under the circumstances, the court ordered the municipality to pay the costs of the aggrieved bidder's application for interim relief, including the costs it had incurred in trying to obtain information from the municipality pertaining to the award decision.

63 S 217 Constitution.

642 of 2000. 


\section{Bibliography}

Bolton 2009 PER

Bolton P "The committee system for competitive bids in local government" 2009 PER 12(2) 56-96

Quinot 2008 JQR

Quinot G "Public procurement" $2008 J Q R 3^{\text {rd }}$ issue, accessible at http://www.jutalaw.co.za

Steytler and De Visser Local Government Law

Steytler N and De Visser J Local Government Law of South Africa (LexisNexis Butterworths South Africa 2007)

\section{Register of legislation}

Constitution of the Republic of South Africa, 1996

Local Government: Municipal Finance Management Act 56 of 2003

Local Government: Municipal Systems Act 32 of 2000

Promotion of Access to Information Act 2 of 2000

Promotion of Administrative Justice Act 3 of 2000

\section{Register of government publications}

GN 868 in GG 27636 of 30 May 2005

\section{Register of cases}

CC Groenewald v M5 Developments (283/09) [2010] ZASCA 4731 March 2010 Koyabe $v$ Minister for Home Affairs Case CCT 53/08 [2009] ZACC 2325 August 2009

Loghdey v Advanced Parking Solutions CC Case 20766/2008 (W) [2009] ZAWCHC 1525 February 2009 (unreported) 
Lohan Civil-Tebogo Joint Venture v Mangaung Plaaslike Munisipaliteit Case 508/2009 (O) [2009] ZAFSHC 2127 February 2009 (unreported)

M5 Developments (Cape) (Pty) Ltd v CC Groenewald NO Case 6277/08 [2009]

ZAWCHC 312 February 2009

Mohammed Zunade Loghdey v City of Cape Town; Advanced Parking Solutions CC v City of Cape Town Case 100/09 [2010] ZAWCHC 2520 January 2010 Moseme Road Construction CC v King Civil Engineering Contractors (Pty) Ltd (385/2009) [2010] ZASCA 1315 March 2010

Municipality of the City of Cape Town v Reader 20091 SA 555 (SCA)

Nichol v Registrar of Pension Funds 20081 SA 383 (SCA)

Oudekraal Estates (Pty) Ltd $v$ City of Cape Town 20046 SA 222

Reader v Ikin 20082 SA 582 (CPD)

Reed v Master of the High Court of South Africa [2005] 2 All SA 429 (E)

Robcon Civils/Sinawamandla 2 Joint Venture v Kouga Municipality 20103 SA 241 $(\mathrm{ECP})$

Syntell (Pty) Ltd v The City of Cape Town Case 17780/07 (CPD) [2008] ZAWCHC 12013 March 2008 (unreported)

Total Computer Services (Pty) Ltd v Municipal Manager, Potchefstroom Local Municipality 20084 SA 346 (T)

\section{List of abbreviations}

BAC

bid adjudication committee

BEC bid evaluation committee

JQR Juta's Quarterly Review of South African Law

PAJA Promotion of Administrative Justice Act

PER Potchefstroom Electronic Law Journal 